DOROTA KULCZYCKA

\title{
JAN PAWEŁ II W SURREALISTYCZNYCH ODSŁONACH DWA FILMY - O TEATRACH I TEATRZYKACH I NIE TYLKO - „Z UDZIAŁEM” PAPIEŻA
}

Przedmiotem niniejszej refleksji są takie surrealistyczne filmy, jak Spiskowcy rozkoszy (Spiklenci slasti - 1996) i Być jak John Malkovich (Being John Malkovich - 1999), w których zostały użyte w formie montażu materiały filmowe z udziałem Jana Pawła II, a teatr odgrywa dość znaczącą rolę bądź jako jeden z wiodących tematów, bądź też jako konwencja artystyczna. Jaki sens mają te przywołania? Co komunikują? Jakie jest miejsce Autora Przed sklepem jubilera w tak dalekim wydawałoby się od duchowości katolickiej surrealizmie?

Jak przekonują badania przeprowadzone przez Anastazję Seul, Jan Paweł II w swoich przemówieniach i homiliach nawiązywał przede wszystkim do klasyki literatury krajowej i światowej - do utworów o charakterze patriotycznym, narodowym bądź religijnym. Tropiąc odwołania do twórczości rodzimej, autorka wykazała, że szczególnie upodobał on sobie dzieła romantyków: Cypriana Norwida, Juliusza Słowackiego, Adama Mickiewicza, Zygmunta Krasińskiego, a także: Bogarodzice, utwory Wincentego Kadłubka, Jana Kochanowskiego, ks. Piotra Skargi, Stanisława Wyspiańskiego i Artura Oppmana. Wychowywał „swoich słuchaczy i czytelników ku temu, by wartości sakralne pozostawały zawsze na pierwszym miejscu w ludzkim życiu" (Seul 217). Pielgrzymując do różnych krajów, wymieniał w kolejnych przemówieniach przede wszystkim tych twórców, którzy pozostawali w łączności z odwiedzanymi przezeń narodami - najczęściej jednak byli to poeci, dramaturdzy,

Dr hab. DoRota KulCZYCKA, prof. UZ - Zakład Teorii Literatury i Krytyki Literackiej w Instytucie Filologii Polskiej UZ; adres do korespondencji: Uniwersytet Zielonogórski, al. Wojska Polskiego 69, 65-762 Zielona Góra; e-mail: D.Kulczycka@ifp.uz.zgora.pl. ORCID: http://orcid.org/0000-00022608-3620. 
powieściopisarze i filozofowie wnoszący wielki wkład w życie kulturalne świata, często też sami wyznający wartości religijne i patriotyczne. Jan Paweł II odnosił się do dzieł „wartościowych”, uczących postaw patriotycznych, religijnych i humanitarnych, natomiast do jego sylwetki nawiązywali twórcy rozmaitych gatunków literackich i filmowych. Spośród filmów wyróżniają się produkcje dość odległe od zainteresowań kulturowych Karola Wojtyły, jak serial kryminalno-komediowy Detektyw w sutannie (1989-1991), komedia kryminalna Różowa Pantera (2006), gangsterska Opowieść kryminalna (2005), sensacyjny Banal (2008), komedie sensacyjne Naga broń 33 1/3: Ostateczna zniewaga (1994) i Kiler-ów 2-óch (1999); katastroficzny Armageddon (1998) czy filmy komediowe o znamionach surrealizmu. Mając na uwadze tę ostatnią grupę, omówię w niniejszym artykule dwa filmy, które łączy nie tylko postać Ojca Świętego (obecnego przez moment za sprawą zmontowanych materiałów dokumentalnych), ale również wątek teatru. Być jak John Malkovich (1999) oraz Spiskowcy rozkoszy (1996) nawiązują bowiem do konwencji widowisk jarmarcznych, ludowych, w których chętnie wykorzystywano takie rekwizyty jak kukły i kukiełki, pacynki i manekiny.

Teatr, jak wiadomo, był bardzo ważną dziedziną zainteresowań przyszłego Biskupa Rzymu. Czy w takiej wersji, jak zaprezentowana w powyżej wzmiankowanych obrazach, odpowiadałby jego światoodczuciu i filozofii? To pytanie, w dużej mierze retoryczne, aczkolwiek ważne, musi zejść na dalszy plan. Istotniejsze wydają się kwestie: jaką rolę odgrywają w tych filmach migawki przedstawiające Papieża; epizody, w których instrumentalnie wykorzystano jego wizerunek? Jakie jest jego miejsce w fantastycznych i fantasmagorycznych światach wykreowanych przez Jana Švankmajera i Spike'a Jonze'a?

\section{SPISKOWCY ROZKOSZY (SPIKLENCI SLASTI, 1996)}

Konrad J. Zarębski, jeden z najbardziej znanych polskich filmoznawców, pisze: „Marginalizując [...] znaczenie surrealizmu, nie mamy często świadomości, że surrealizm żyje i ma się całkiem nieźle. Co więcej, nie domyślamy się, że stolicą współczesnego surrealizmu jest czeska Praga, kojarzona zwykle z Kafkowskim katastrofizmem" (Zarębski 35).

Najbardziej rozpoznawalny jest ów kierunek w filmach Jana Švankmajera, który mówil, że historycy sztuki uwięzili surrealizm w przeszłości, natomiast jego własny „bardzo bliski [jest] rudolfińskiemu manieryzmowi” (Švankmajer 23). Chociaż dzieła Švankmajera wyłamują się z jednoznacznych ram gatunkowych, Spiskowców rozkoszy można uznać za utwór surrealistyczny, łączący żywych aktorów i lalki, a więc elementy teatru, ale też animację poklatkową, której reżyser jest niedości- 
głym mistrzem (Černy b.s.) ${ }^{1}$. Film uchodzi za „czarną komedię”, jest w pewnym sensie, jak niemal każde dzieło surrealistyczne, obrazem psychologicznym, ale także - pornograficznym - wyraźnym nawiązaniem do powieści Markiza Sade’a tyleż wobec niego czołobitnym, co parodystycznym. Został oparty też na eseju reżysera z 1975 roku zatytułowanym nie inaczej, jak: Przyszłość należy do maszyn masturbacyjnych (zamieszczonym we francuskiej antologii Vincenta Bounoure'a $\mathrm{La}$ civilisation surréaliste).

Jan Švankmajer (urodzony w 1934 roku) jest wybitnym czeskim reżyserem, rzeźbiarzem, eseistą i poetą; podobnie jak Karol Wojtyła: człowiekiem znanym, wszechstronnie uzdolnionym, doświadczonym przez historię. Studiował -

w Wyższej Szkole Rzemiosł Artystycznych oraz na Wydziale Teatralnym Akademii Muzycznej w Pradze, a także współpracował z Teatrami Černé divadlo i Laterna magika. W latach 19641969 nakręcił dziesięć filmów, w tym cztery z udziałem żywych aktorów. Od samego początku nie ograniczał się do jednego gatunku lub medium, zajmując się zarówno grafiką, rzeźbiarstwem, jak i ceramiką. (Hames, Czechostowacka Nowa Fala 265)

W latach 1973-1980 nie wolno mu było kręcić filmów, wtedy działał w grupie surrealistów. Znamienną cechą dzieł scenicznych, a potem filmowych Švankmajera było łączenie gry lalek ,z grą aktora w masce”, animacji „,wielkich marionetek z aktorem ukrytym wewnątrz lalki. [...] Jego artystyczne działania wyraźnie wkraczały w przestrzeń surrealizmu" (Tomaszewska 70). Sztuka teatralna Švankmajera, przenoszona do filmu, była przede wszystkim dziełem wyobraźni, kontestacji i manifestowania niezależności twórczej - również od systemów politycznych. Surrealizm odpowiadał więc reżyserowi w owych tendencjach najbardziej, rozumiany zresztą przezeń nie tyle jako sztuka, ile wewnętrzna predyspozycja i konieczność. Jak pisze Peter Hames:

Mimo że Švankmajer dołączył do Praskiej Grupy Surrealistycznej dopiero w 1970 roku, to uważał się za surrealistę już dużo wcześniej. Tworząc w surrealistycznej atmosferze ciągłej rewolucji, podkreślał, że surrealizm nie jest sztuką: ,Surrealizm jest podróżą w głąb duszy, podobnie jak alchemia i psychoanaliza" ["Interwiev with Jan Švankmajer" 104]. Jego głównym celem pozostaje zmienianie świata [Marks] i życia [Rimbaud]. (Czechosłowacka Nowa Fala 267-268)

W rozmowie z Bogusławem Zmudzińskim artysta potwierdził, że to nie artyści wybierają surrealizm, ale surrealizm wybiera ich i że kierunku tego nie można rozumieć w kategoriach sztuki, gdyż jest „to rewolucyjny pogląd na życie i świat, to roman-

${ }^{1}$ Z kolei Konrad J. Zarębski pisze, że film Spiskowcy rozkoszy grany jest przez aktorów, ,a przecież nie sposób obronić się przed wrażeniem, że od początku do końca mamy do czynienia z filmem lalkowym. To przede wszystkim zasługa fotografowania postaci i ich animowania - nawet w partiach stricte aktorskich" (35). 
tyzm XX wieku i dopóki nie ukształtuje się nowy romantyzm, surrealizm będzie przyciągać następne generacje. Surrealizm jest [...] przede wszystkim kolektywną przygodą, postawą antycywilizacyjną, stale pociągającą młodych" (Švankmajer 56).

Dla Švankmajera skutecznymi metodami walki czy to ze stalinizmem, czy też potem z ideologią konsumpcjonizmu były utrzymane w owej konwencji: ,sarkazm, cynizm, wyobraźnia i mistyfikacja" (Hames, "Interwiev with Jan Švankmajer" 105). Kiedyś określił swoją pracę jako „surrealistyczne śledztwo” - próbę wyzwolenia uczucia strachu i boleści za pomocą takich „narzędzi” jak „humor obiektywny i czarny humor" (Král 28)2. Realizował to we właściwym sobie, szokującym i kontrowersyjnym stylu, wprowadzając wątki pornograficzne i nadrealistyczne, związane z poetyką absurdu. Nie ulega wątpliwości, że Jan Paweł II proponowałby całkiem inne sposoby kontestacji.

Wybitne miejsce Švankmajera wśród reżyserów sztuk i filmów z udziałem pacynek, kukieł i manekinów nie oznacza zupełnej jego autonomiczności w dziedzinie lalkarstwa. Jego dzieła były poniekąd też wyrazem przemian w czechosłowackim teatrze lalek, dotyczących przede wszystkim rozszerzania form i technik, z wykorzystaniem telewizji i telewizora włącznie. Eksperymentowano przy tym z relacjami przestrzennymi, zrywając z jednością miejsc, wykorzystując lustra i szkła, wprowadzając oniryzm i wizyjność, multiplikując przedmioty i przestrzenie. Dobrym przykładem jest właśnie telewizor w Spiskowcach rozkoszy, jako splot techniki, elektroniki i szkła, miejsce przechodnie między światem news-ów a przestrzenią widza; między dziennikarką a adorującym ją bohaterem. W takim ekranie w 12 minucie (dokładnie 12’05 w trakcie trwającego 82’22 minuty filmu) pojawia się kadr z Janem Pawłem II - migawka z telewizyjnej relacji z jakiejś jego pielgrzymki. Widzimy Ojca Świętego w powiewającym żółtym płaszczu, z pastorałem, w otoczeniu służby liturgicznej, kapłanów i sióstr zakonnych. Nie mamy pewności, z jakiego miejsca i czasu jest wkomponowane w film nagranie. W ojczyźnie Švankmajera, przed premierą omawianego filmu, Jan Paweł II był dwukrotnie: w 1990 roku w Czechosłowacji, natomiast w 1995 roku - w Czechach. 21 kwietnia 1990 roku w Pradze na Hradczanach wzywał młodych, by pragnęli wartości duchowych, a nie materialnych; by szukali prawdy i sensu życia. Głosił, że źródłem materializmu jest lęk przed nicością, ,kiedy człowiek jest oderwany od rzeczywistego sensu swego życia”, od Transcendencji (Jan Paweł II, Dzieła zebrane 9: 784).

Rozmaite lęki (o zauważenie bądź niezauważenie przez innych; przed człowiekiem lub wskutek braku człowieka; w związku z odpychaną, nieodwzajemnioną

\footnotetext{
${ }^{2}$ Odpowiadałoby to typowi poczucia humoru Czechów, który E. Tomaszewska scharakteryzowała jako pełen ,absurdu, przerysowania i czarnej komedii” (266).
} 
miłością albo na skutek odczucia pustki egzystencjalnej; bezsensu i samotności; okrucieństwa i przemocy; sadyzmu i masochizmu) są przedmiotem Spiskowców rozkoszy. Ale Švankmajer nie daje takich odpowiedzi, jakie jednoznacznie wypływają z papieskiego przemówienia. „Zmysł przekraczania widzialnej rzeczywistości” realizuje się tu w nad-rzeczywistości, a nie we wspomnianej przez Ojca Świętego Boskiej Transcendencji. Tkankę semantyczną jego dzieła spowija nie tylko lęk, ale i strach, gdyż - jak twierdzi artysta - jego filmy to poezja, ale ta, która nie jest wolna od okrucieństwa. Strach i trwoga to przecież jego obsesyjne tematy, demony, które wracają z czasów dzieciństwa napiętnowanego traumą II wojny światowej. Strach ten potęgowany jest obecnym też przeczuciem zmierzchu cywilizacji (por. Švankmajer 56).

Konwencja parodystyczna i sarkastyczna nie pozwala jednoznacznie stwierdzić, czy obrazy pornograficzne i sceny perwersji, egoizmu, hołdowania dziwacznym namiętnościom są alternatywą dla pozbawionego wyższej kultury świata, czy też są „znakiem sprzeciwu” wobec niego. Jednak nawet gdyby tak było, reżyser nie daje żadnej konstruktywnej propozycji, a przywoływania pewnych ,autorytetów”, jakże dalekich od ducha ewangelii, raczej nie można poczytywać za (auto)ironiczny zabieg (por. Hames, Czechostowacka Nowa Fala 334-335)3.

Film zaczyna się od pokazania na tle pogodnej quasi-ludowej muzyki obrazków, przedstawiających wyuzdane sceny, a będących ilustracjami do prozy Markiza de Sade (m.in. do holenderskiego wydania jego Justine ou les malheurs de la vertu 1791); kończy zaś napisami, które również mogą szokować, jak cały zresztą film. Czy owe napisy są częścią surrealistycznej gry? Oto bowiem czytamy, że „odborni poradci” (czyli ‘fachowi doradcy') to: Leopold Sacher-Masoch (od jego nazwiska pochodzi pojęcie masochizmu); Donatien Alphonse François de Sade (od niego znów - pojęcie sadyzmu); Sigmund Freud; Luis Buñuel (hiszpański reżyser filmowy i scenarzysta związany z surrealistami, m.in. Salvadorem Dali, z którym w 1928 roku nakręcił Psa andaluzyjskiego); Max Ernst (niemiecki malarz, rzeźbiarz, grafik i pisarz surrealistyczny, uczestnik seansów spirytystycznych) i Bohuslav Brouk (czeski psychoanalityk, propagator psychoanalizy Freuda). Dalej czytamy:

dáje hrani ['dalej grają' - DK]

Papež JAN PAVEL II

MILAN UHDE ['czeski dysydent i polityk, członek ODS' - DK]

a ['i' - DK]

neznámý vojin ['nieznany żołnierz'- DK]

\footnotetext{
${ }^{3}$ Na pewno jednak reżyser uważał, że: „Twórczość jest zawsze pewną terapią” (Švankmajer 56).
} 
Są to oczywiście nieprawdziwe dane, gdyż np. Jan Paweł II pojawia się na zasadzie spreparowanego przez filmowców montażu, a nie jako cameo ${ }^{4}$. Tak samo niewiarygodne wydaje się umieszczenie informacji o muzyce będącej składanką dzieł „George'a Philippa Telemanna, Ruggiera Leoncavalla, Amilcare Ponchielligo, Petra Iljiče Čajkovského a Jaroslava Jankovce”, również: „ruských chorálnich pisni ze 17. stol. a improvizace na Indické lidové motivy". Natomiast patronat Freuda, Sacher-Masocha, de Sade'a i Buñuela jest w tym filmie raczej oczywisty i wyraźnie wyeksponowany.

W 1992 roku nastąpił rozpad Czechosłowacji na Czechy i Słowację. Janowi Pawłowi II dziękowano, że pomógł przezwyciężyć komunizm w Europie Środkowej. Papież przyjechał do Czech w 1995 roku, na rok przed premierą omawianego filmu. W Ołomuńcu, w związku z kanonizacją św. Jana Sarkandra i św. Zdzisławy z Lemberku mówił o powołaniu do świętości wszystkich chrześcijan, również tych, zebranych na spotkaniu: „Tylko to bowiem jest naprawdę ważne w naszym życiu” („Rozważanie przed modlitwą «Regina caeli»», b.s.).

Chociaż Jan Švankmajer w systemie komunistycznym (socjalistycznym) widział źródło zła i bezprawia, tworzył takie sztuki, również po obaleniu systemu, które nie odpowiadały papieskiemu wezwaniu do świętości, do szukania ewangelicznej, opartej na Chrystusie, duchowości. Trzeba zatem zapytać: w jakim kontekście i w jakim celu reżyser wprowadził obraz Jana Pawła II witanego przez księży i siostry zakonne?

Wizerunek Ojca Świętego pojawia się w telewizorze u anonimowego, określanego ewentualnie jako „kupiec gazet”, bohatera, którego gra Jiří Lábus. Powaga najważniejszych wydarzeń z kraju i zagranicy, prezentowanych przez Panią Beltinską (gra ją Anna Wetlinska), osłabiona zostaje poprzez erotyczne ukontekstowienie sceny. Z obrazem spikerki zakochany w niej sklepikarz czyni różne eksperymenty: przybliża jej twarz na ekranie, by móc ją pocałować. Tworzy mechaniczne ręce, imitujące jej dłonie, aby w czasie owego osobliwego zbliżenia, wprawione w ruch, mogły go dotykać. Mechanizm owych sztucznych rąk, sterowanie nie tylko nimi, ale również obrazem na ekranie telewizyjnym, ma wyraźnie surrealistyczne konotacje: erotyka jest sprzęgnięta z mechaniką, z multiplikacją; surrealistyczny ideał miłości szalonej (zob. na ten temat np.: Breton 120; Wielebska 105) przekłada się na erotyczne fantazmaty i obsesje.

\footnotetext{
${ }^{4}$ Cameo - krótki udział znanej osobistości (np. aktora, muzyka lub polityka) w filmie, serialu lub grze komputerowej. Często osoba taka nie jest wymieniona w czołówce lub napisach końcowych. Camea występują w takich filmach, jak Zelig Woody'ego Allena (1983), Gracz Roberta Altmana (1992), w pewnym sensie też Ocean's Twelve: Dogrywka (reż. Steven Andrew Soderbergh, USA 2004) itd.

${ }^{5}$ Film „Spiskowcy rozkoszy”, Centrum Edukacji i Inicjatyw Kulturowych w Olsztynie, www. ceik.eu/aktualnosci-kalendarium/artykul/article/film-spiskowcy-rozkoszy.html. Dostęp 11.02.2020.
} 
Obraz Jana Pawła II nie zostaje poddany przekształceniom i manipulacjom, lecz głos - w owym niemym filmie, w którym żaden główny czy poboczny bohater nie wypowiada ani jednego słowa - już tak. Zagłuszane muzyką odgłosy z wizyty duszpasterskiej Ojca Świętego są bricolage'ową kompilacją jego przemówień z różnych pielgrzymek. W tym ledwo słyszalnym głosie możemy domyślać się słów z języka hiszpańskiego: „esperada” ('oczekiwany'), „los cristianos” (“chrześcijanie'). Niewyraźnie słychać też polskie wyrazy: „znów otwiera bolesne rany”. W kontekście czarnego humoru, purnonsensu i poetyki absurdu krążącej wokół sadomasochistycznych fantazji wszystkich bohaterów owego niemego filmu, obecność przemawiającego do thumów, realnego Jana Pawła II nabiera mimo wszystko nierealnych znamion. Nawet jeśli on tam coś mówi, nie mówi do reszty bohaterów - głos zdaje się, że jest oderwany od obrazu. Pomieszanie obrazów, dźwięków, ich natłok, kakofonia, brak hierarchii i brak porządku to cechy charakterystyczne dla współczesnego, postmodernistycznego świata. Figura Ojca Świętego - zwolennika ładu i harmonii pojawia się na zasadzie wyraźnego kontrastu wobec tak zaprezentowanego uniwersum.

Papież staje się w tym filmie epizodycznym bohaterem, ale i ofiarą surrealistycznej gry. Pozostaje czysty, nieskalany, ale też pochodzący jakby z podwójnie innego świata. Obcy wobec mieszkańców Czech i obcy wobec filmowych, fantastycznych postaci. Nagrania archiwalne w kontekście całości dzieła nabierają nowych, niepożądanych znaczeń: uśmiechy sióstr zakonnych witających Papieża wydają się na tle zsekularyzowanego i zerotyzowanego świata ludzi-kukieł jakieś dwuznaczne, skażone zmysłowością. Oczywiście jest to iluzja powstała pod wpływem filmu.

Pomijając, że akcja toczy się w Pradze (i na jej peryferiach), w stolicy kraju doprowadzonego przez różne ustroje do prawie zupełnego zeświecczenia, bohaterowie bynajmniej nie szukają głębszej duchowości, pławiąc się w substytutach erotycznych rozkoszy, perwersyjnym okrucieństwie i przemocy, ulegając nieszczęśliwie, gdyż bez jakiejkolwiek więzi z realnie istniejącym drugim człowiekiem, żądzom i namiętnościom. Wszystko rozgrywa się na płaszczyźnie materialnej i somatycznej, a nie duchowej. Szczotki, lisie ogony, bawełniane strzępy i waciki, żywe karpie, kulki z chleba, ekran telewizora, sztuczne ręce, torturowane lalki wyobrażające płeć przeciwną stają się elementem ich podniecenia, ,erotycznej ekstazy” i seksualnego „wyżycia się”. Czasem owej gry, owego tytułowego „spisku” jest niedziela i jest to niedziela oczywiście bez liturgii, bez kościoła, bez Boga, choć elementy religijne, aczkolwiek sprofanowane, pojawiają się w postaci śpiewów gregoriańskich towarzyszących działaniom głównego bohatera - Peony’ego oraz demonicznej pani Lubalovej odprawiającej niejako czarną mszę i maltretującej w niej ożywioną kukłę. Rytuał z sadystycznym zarżnięciem koguta, scedzaniem najpierw do kielicha (por. Ostatnia Wieczerza), a następnie do czerwonego balonika jego krwi, preparowaniem maski z jego piór przypomina tyle religijny, ile satanistyczny obrzęd. Zresz- 
tą towarzyszą mu śpiewy gregoriańskie z powtarzanym motywem Kyrie eleison. Dzieje się to w obskurnej starej kamienicy, przypominającej zniszczony kościół, w której stoi tylko krzesło z balią wypełnioną wodą, na poręczy krzesła palą się trzy świece, a dookoła panuje półmrok. To nie jest nabożeństwo, lecz ceremonia sadomasochistyczna z biczowaną kukłą Peony’ego - ożywiającą się, rozbierającą się na rozkaz dręczycielki; imitacją człowieka z popękaną, w końcu porozdzieraną od sadystycznych smagnięć skórą-płótnem itd. Analizowanej scenie (która zresztą ma swoje lustrzane odbicie - różne libidalne fantazje Peony w tym samym czasie spełnia z wywiezioną w plener imitacją pani Lubalovej) reżyser nadaje znamiona jakiegoś sacrum - sacrum odwróconego, sacrum złowieszczego. Możliwe, że takie konotacje ma również chleb, który listonoszka (Barbora Hrzánová) obsesyjnie wydrąża ze skórki, zamieniając w małe kulki, a jego skorupę wyrzucając do śmieci. Owe kulki w zaciszu domowym wdycha przez nos przed zaśnięciem. Sprofanowane w ten sposób symbole Chrystusa z Wieczerzy Pańskiej - niszczony chleb i kielich nie z winem, lecz z krwią (koguta - znaku w niektórych wierzeniach sił tyle boskich, co demonicznych - por. Cooper $102^{6}$ ) wydają się wymowne również na tle telewizyjnego obrazu z Janem Pawłem II, którego przyjazdy do różnych krajów zawsze uświetniała Eucharystia. Można zastanawiać się, czy reżyser w ten sposób chciał sprowokować widzów do refleksji nad miejscem sacrum we współczesnym, zsekularyzowanym świecie, czy jedynie proponował nową formę „duchowości” bądź zabawy z religijną konwencją.

W kontekście paranoidalnej sytuacji wszystkich bohaterów „spektaklu” Papież staje się „newsem”, faktem medialnym, figurą rzeczywistości nieobchodzącą bohaterów tak, jak nie obchodzą ich pożary, powodzie, katastrofy, zamieszki uliczne, polityka itd., nawet wówczas, gdy o nich informuje ktoś nieobojętny. Mam na myśli poruszającą ustami, przewracającą głośno kartkami, ale właściwie „nieobecną duchem" spikerkę Annę Wetlinską - niekochaną przez męża, odnajdującą rozkosze w kontakcie z kupionymi żywymi karpiami, adorowaną z kolei przez nieznanego jej sprzedawcę ze sklepiku z gazetami. Wiemy, że owa kobieta z przymglonymi pożądaniem oczyma coś mówi, ale treści możemy się domyśleć jedynie na podstawie poruszanych ust, szeleszczących kartek i kadrów rejestrujących różne wydarzenia ze świata. Jednym z nich jest właśnie obraz z Ojcem Świętym. Kontrowersyjne wydaje się jego usytuowanie w kontekście ludzi, machin i urządzeń elektrycznych, złowieszczo skrzypiącej szafy (jeden z najważniejszych przedmiotów w tym filmie), antropomorfizowanych, ożywianych kukieł włączonych w sadomasochistyczną za-

${ }^{6}$ „Krew koguta jest istotnym składnikiem rytuałów ju-ju, zwłaszcza podczas obrzędów inicjacji, a także w wudu". Cooper 104. Na temat symboliki koguta zob. też: Saunders 121 oraz Kopaliński $149-151$. 
bawę. W tej produkcji nie ma chyba miejsca dla chrześcijańskiej wizji człowieka. Prawda o nim, jako istocie posiadającej ciało i duszę, dążącą do Boga, zastąpiona jest tu m.in. nauką Freuda o sferze Id (das Es) i libido. Z drugiej jednak strony patrząc, zdajemy sobie sprawę, iż oceniając filmy fabularne, a zwłaszcza surrealistyczne, nie powinno się zwracać uwagi na (nie)moralność. Są to produkcje, w których mamy raczej „podziwiać” pomysłowość, grę wyobraźni i technikę służącą nowym rozwiązaniom formalnym. Rzecz dotyczy też drugiego z omawianych tu filmów.

\section{BYĆ JAK JOHN MALKOVICH (BEING JOHN MALKOVICH, 1999)}

Utwór ten uważany jest, nawet przez samego reżysera Spike'a Jonze'a, za komedię ${ }^{7}$. Może uchodzić za film psychologiczny, a ze względu na pewne ujęcia i zastosowane techniki - jest na pewno też dziełem surrealistycznym. Według innych bywa zaliczany do „kina schizofrenicznego"

Obie produkcje, stworzone w tym samym mniej więcej czasie (lata dziewięćdziesiąte XX wieku), wiele różni, ale też wiele łączy. Różni je na pewno konwencja artystyczna (choć $\mathrm{w}$ jednym i drugim przypadku mamy do czynienia $\mathrm{z}$ formalnym eksperymentem, polegającym na multiplikacjach i osiąganym w ten sposób przez bohaterów efekcie sublimacji i substytucji), różni je aglomeracyjna sceneria i tło wydarzeń (postkomunistyczna Praga a kapitalistyczne Stany Zjednoczone, w których rzekomo najważniejsze jest „robienie na wszystkim interesów”), różni je fonia: muzyka i znaczenie dialogów. W niemym filmie Švankmajera muzyka odgrywa dużą rolę - w produkcji z 1999 roku, w której z kolei nie brakuje rozmów, jest niemalże niezauważalna. Oba zaś filmy łączy wspomniany surrealizm: eksperymentatorskie zabawy z przestrzenią (tajemne przejścia do innego wymiaru rzeczywistości, spośród których w jednym i drugim przypadku główną rolę odgrywają szafy i ukryte za nimi „tunele” do innej rzeczywistości; rembrandtowskie operowanie odcieniami czerni i ciemnego brązu); multiplikacje i przekształcenia rzeczy i osób; gra z tożsamością bohaterów; modyfikacje w koncepcji miłości szalonej (w Być jak John Malkovich skomplikowanej ponadto przez różne genderowe inwarianty); wyostrzona problema-

${ }^{7}$ „Wprawdzie mój film jest komedią, ale chciałem, żeby postaci w nim występujące były jak najbardziej realne" (Jonze i Dębska 108). Jako komedię określili film m.in.: Beata Pasek oraz Maria Kornatowska. Ta ostatnia dodała jeszcze inne epitety: „Być jak John Malkovich jest filmem nieodparcie śmiesznym w najlepszej tradycji komedii absurdalnej i surrealistycznej” (40). „Komediową fantazją” nazwała produkcję Monika Wiśniewska (20).

${ }^{8}$ Na podstawie Być jak John Malkovich oraz Być jak Stanley Kubrick Jacek Szczerba dochodzi do wniosku, że: „Kino schizofreniczne najwyraźniej pasuje do Malkovicha. [...] Teraz Malkovich gra geja Alana Conwaya, który naciąga ludzi, podając się za Stanleya Kubricka” (17). 
tyka ludzkich pożądań (w amerykańskim filmie: nie tylko zmysłowych namiętności, ale również żądzy sławy i pieniędzy, wiecznej młodości i nieśmiertelności); problem samotności człowieka i kwestionowanego sensu jego istnienia, w końcu zaś - teatr lalek i motyw z Janem Pawłem II jako postacią występującą w telewizji.

W filmie Jonze'a przewija się kilka wątków. Mimo obowiązującej w nim surrealistycznej konwencji, która nieraz dewaluuje sens pytania o przesłanie ${ }^{9}$, trzeba jednak stwierdzić, że poruszone są też różne, ważne dla ludzkości problemy: „Ta komedia stawia całkiem poważne pytania" - pisze w recenzji Beata Pasek (b.s.). Film nie jest łatwy, gdyż nie pokazuje niczego wprost. Mówi o niezaspokojonym pragnieniu miłości, dowartościowania, a także wiecznego życia. Jedną z najważniejszych jest scena rozpaczliwego tańca człowieka niepogodzonego z samym sobą: „Taniec rozpaczy i rozczarowania”. Charakterystyczny jest tam - domagający się psychoanalitycznej interpretacji - motyw rozbicia w desperacji lustra (np. czas: 84'59). Po raz pierwszy całą scenę odgrywaną przez kukiełki widzimy w teatrzyku lalkowym Craiga Schwartza (John Cusack - czas: 00’37-02’28). Po raz drugi w czasie, gdy Maxine (Catherine Keener) inkarnowanemu w aktora Craigowi każe odegrać ją na żywo, posługując się Malkovichem niczym bezwolną kukłą. Na sugestię Craiga-Malkovicha: „--Widzisz, to nie jest zwykła zabawa lalkami”, oszołomiona wirtuozerią tańca Maxine odpowiada: ,-- Oh, kochany, to coś więcej. To zabawa ludźmi” (czas: $\left.84^{\prime} 53-85^{\prime} 04\right)$.

O autentycznym Johnie Gavinie Malkovichu zwykło się mówić, że jest aktorem niezwykle elastycznym: „Kameleonem, który uwiarygodni każdą rolę, dając jej intrygującą niejednoznaczność” (J. Gajda-Zadworna i B. Zadworna 47). Dlatego świetnie pasuje do roli, jaką miał odegrać w omawianym tu filmie (Johna Horatio Malkovicha - jest to jedna z gier filmowców sugerujących identyczność), ale także w Być jak Stanley Kubrick.

Jak do tego doszło, że w dziele Jonze'a sławny aktor utożsamiany z autentyczną postacią stał się „tubą”, w której mogą się znaleźć różne osoby? Otóż, pracując w dziwacznej firmie 105-letniego erotomana marzącego o nieśmiertelności - na piętrze „siedem i pół”, Craig odkrył za szafą tzw. portal - ciemny tunel, przez który wchodzi się do głowy Malkovicha. Wraz ze współpracownicą Maxine robią biznes na tych, którzy chcą widzieć świat oczyma sławnego aktora. Ten ostatni służy jako środek do osiągnięcia też innych (osobistych, uczuciowych, towarzyskich, prestiżowych itd.) celów, co zdradzają słowa Craiga skierowane do żony Lotte (Cameron Diaz): „Trochę treningu i Malkovich będzie kolejną marionetką w mojej pracowni”

\footnotetext{
${ }^{9}$ Monika Wiśniewska pisze, że „szukanie głębszych pokładów myślowych, a nawet przesłania [...] nie przystoi, jak wiadomo, szanującemu się filmowi rozrywkowemu" (20). Podobnie uważa Konrad J. Zarębski: „trudno dyskutować o przesłankach, gdy w grę wchodzi podświadomość” (35).
} 
(63'45-63'49). Malkovich nie rozumie tego, co się z nim dzieje; dlaczego nie panuje nad swym ciałem, dlaczego stał się bezwolną kukłą sterowaną przez siły, które są w nim, a których nie rozpoznaje jako własne. Nękany ponadto przez molestującą go Maxine, chce poznać powody swoich dziwnych zachowań i - uciekając się do fortelu - odwiedza półpiętro. Od smutnego człowieka stojącego w kolejce (Gerald Emerald) dowiaduje się o usługach firmy: „Przez 15 minut jesteś Johnem Malkovichem... za 200 dolarów" (czas: 67'11-67’33). Sam Craig thumaczy zdenerwowanemu aktorowi, który mało nie został pobity przez kolejkowiczów:

- Nasza firma oferuje klientom symulację bycia panem.

- Symulację?

- Tak, interaktywną. $\left(68^{\prime} 14-68 ’ 26\right)$

Film opowiada o żądzach ludzkich, o ludzkiej pysze i egoizmie. Kiedy sławny aktor wchodzi do swojego własnego portalu, nie widzi kelnera, lecz siebie jako kelnera, nie widzi ludzi przy stolikach, tylko multiplikowanego siebie w restauracji; nie widzi solistki, tylko siebie jako solistkę. Wszystkie potrawy nazywają się „Malkovich”, wszyscy tylko tym jednym słowem ze sobą rozmawiają. Czy taka jest prawda o ludziach owładniętych żądzą sławy? Aktor jest przerażony własnym egocentryzmem, gdyż stwierdza: „Widziałem świat, którego nikt nie powinien widzieć” (czas: 71'05). Scenę multiplikacji bohatera krytycy filmowi jednogłośnie uznają za najgenialniejszą w całym dziele (zob. np. Kornatowska 40).

Najbardziej wykorzystają Malkovicha Maxine i Craig, odnosząc komercyjne sukcesy i zdobywając rozgłos. Fotografują się i pozują do kamer telewizyjnych w scenerii bogato wystrojonych wnętrz i w najdroższych ubraniach. Na jakimś lotnisku Schwartz-Malkovich robi sobie zdjęcie z Janem Pawłem II. Znamienne, że w tym mniej więcej czasie narrator mówi: „Jaka przyszłość czeka Johna Honoriusza Malkovicha? [...] On trzyma świat na sznurku” (czas: 92'31-92’33).

Jan Paweł II w tym surrealistycznym filmie występuje dzięki technice montażu. Pojawia się na podobnej zasadzie jak Sean Penn (rzekomo zauroczony grą lalkarza Schwartza-Malkovicha), Brad Pitt i inne gwiazdy, których znajomością szczyci się mieszkający w ciele Malkovicha Craig. Spotkania z nimi mają podkreślać jego wysoką rangę społeczną, być znakiem, że lalkarz jest równy najsławniejszym ludziom świata.

Filmografia światowa zna przypadki sytuowania bohatera przy Papieżu Polaku i innych dostojnikach świeckich i duchownych. Ma to walor rozrywkowy lub uprawdopodabniający akcję. Na podstawie takich dzieł można też wysnuć wniosek dotyczący psychologii filmowych postaci: gdy jakiś bohater chce się dowartościować (casus filmu Zbrodnia ojca Amaro, serialu Eureka Street) albo wydaje mu się, że jest już wielki (Być jak John Malkovich, Kiler-ów 2-óch, Różowa Pantera z 2006 
roku), to fotografuje lub filmuje się ze sławnymi osobistościami. Sławomir Bobowski w książce Martin Scorsese i religia pisał, że czym większa desakralizacja świata, tym większa deifikacja „gwiazd” futbolu, kina, polityki itd. (52). Papież, kreowany na modłę światową: zrównany rangą z innymi osobistościami, powszechnie znanymi, byłby więc taką gwiazdą, co oczywiście nie odpowiadałoby w realnym świecie ani jemu, ani ludziom głębokiej wiary.

Tutaj, jak i we wszystkich innych wypadkach, nasuwają się pytania: gdzie leżą granice wykorzystywania wizerunku postaci publicznej w sztuce, również w sztuce filmowej? Czy Jan Paweł II na spreparowanych fotografiach przedstawiających go z bohaterem fikcyjnym, to jeszcze oby na pewno Jan Paweł II? Gdzie rozciąga się linia demarkacyjna między prawdą historyczną, postacią autentyczną a fikcją i postacią fikcyjną? A może trzeba raczej mówić o przenikaniu się, indyferencji świata realnego i świata zmyślonego? Kwestia ta szczególnie silnie wybrzmiewa w filmie Być jak John Malkovich, gdyż to właśnie to pytanie jest jednym z głównych, dotyczących nie tylko przecież ontologii fikcyjnych bohaterów, ale w ogóle człowieczeństwa. Do jakiego stopnia jesteśmy prawdziwi? Jak bardzo jesteśmy autentyczni, a jak bardzo gramy? „Czy jesteśmy kochani takimi, jakimi jesteśmy, czy takimi, jakimi wyobrażają nas sobie ci, co nas kochają? Gdzie jest granica między byciem sobą a byciem osobą, której oczekują od nas inni?" (Pasek).

Niezależnie od tego, czy Jan Paweł II przywołany w filmie jest przedstawiany jako persona grata, czy też - przez zabieg montażu - ośmieszany, stawiany w krzywym świetle, ujmowany ironicznie bądź groteskowo, zawsze jego większy czy mniejszy udział w świecie przedstawionym - jak wiele innych artefaktów - dowodzi, że jako postać realna, historyczna wszedł już za swojego życia do kultury, stał się elementem przestrzeni publicznej, bohaterem medialnym, tyleż autentycznym, co fikcyjnym.

Oba analizowane filmy dowodzą, że Jan Paweł II stał się elementem współczesnej kultury i popkultury, a jednocześnie jej wyraźnym zaprzeczeniem; rozpoznawalną powszechnie osobistością z przełomu wieków, a zarazem wyrazistym znakiem sprzeciwu wobec świata. Może dlatego w filmie Švankmajera jego głos niknie, a w filmie Jonze'a jest w ogóle wyciszony. Mimo surrealistycznej otoczki, pozostaje - dzięki wmontowanym w badane tu dzieła nagraniom archiwalnym - ikoną doniosłych wydarzeń w świecie. Zderzenie jego powagi z galaktyką dziwacznych bohaterów wywołuje efekt dysonansu i konsternację, tym bardziej że oba filmy opowiadają o uleganiu różnym, najczęściej kuriozalnym namiętnościom. W Spiskowcach rozkoszy są to przede wszystkim żądze erotyczne i seksualne; w Być jak John Malkovich - 
żądze powodzenia i sławy (obok różnych konfiguracji żądz zmysłowych). Dochodzi do tego wyraźnie wyeksponowane marzenie, by być kimś innym oraz marzenie o ziemskiej nieśmiertelności. Jan Paweł II ich nie podzielał, wierząc, że ojczyzna jest w Niebie; ufając, że najważniejsze jest spełnianie woli Bożej, poczucie własnej wartości w świetle ewangelicznej prawdy o Transcendencji i o ukochaniu każdego człowieka przez Chrystusa oraz - jak to też często mawiał ks. Piotr Pawlukiewicz - „powrót do siebie” - granie swojej, nie cudzej roli (zob. Pawlukiewicz). Papież całym swoim życiem pokazywał, jak przekraczać własne przyzwyczajenia, jak ponad wszystko czcić Boga i Jego Matkę; jak wychodzić naprzeciw drugiemu człowiekowi, pokonując egoizm i rezygnując z wygody. Jak żyć realnie w rzeczywistej, a nie iluzorycznej przestrzeni.

Analizowane filmy nie odsłaniają głębi nauczania Jana Pawła II. Filmowcy ślizgają się po powierzchni tego, co w jakiś bardzo okrojony, sztampowy sposób kojarzy im się z Ojcem Świętym. Sam Papież jest pewnym kontrapunktem dla surrealistycznych światów stworzonych przez Švankmajera i Jonze'a, w których w miejsce sacrum pojawia się na kilku płaszczyznach quasi- bądź antysacrum. Bycie Papieżem sprowadza się w tych obrazach do jego - jako persona grata - kontaktów z ludźmi na szeroką (Spiskowcy rozkoszy) bądź indywidualną (Być jak John Malkovich) skalę. Zasłużona sława i materialne oznaki godności papieskiej - np. mozzetta, piuska bądź tiara stają się czymś istotniejszym niż wartości, jakim żył Ojciec Święty i ewangeliczny przekaz, jaki niósł światu. Jego wizerunek jako postaci publicznej wykorzystany jest w celach ludycznych, nie ewokując bynajmniej głębszego przesłania.

\section{BIBLIOGRAFIA I WEBGRAFIA}

Bobowski, Sławomir. Między świętościa a potępieniem. Martin Scorsese i religia. Wydawnictwo Uniwersytetu Wrocławskiego, 2007.

Breton, André. „Ankieta na temat miłości”. Surrealizm. Antologia. Przeł. i oprac. Adam Ważyk, „Czytelnik", 1973.

Černy, Milan „gulaulin”. „Jan Švankmajer”, www.csfd.cz/tvurce/3305-jan-svankmajer/. Dostęp 15.07.2013.

Cooper, Jean C. Zwierzęta symboliczne i mityczne. Tłum. Anna Kozłowska-Ryś i Leszek Ryś, Dom Wydawniczy Rebis, 1998.

Film „Spiskowcy rozkoszy”, Centrum Edukacji i Inicjatyw Kulturowych w Olsztynie, www.ceik.eu/ aktualnosci-kalendarium/artykul/article/film-spiskowcy-rozkoszy.html. Dostęp 11.02.2020.

Gajda-Zadworna, Jolanta, i Beata Zadworna. „Być jak Malkovich”. W Sieci, nr 23, 2016, ss. 45, 47.

Hames, Peter. Czechosłowacka Nowa Fala. Tłum. Justyna Burzyńska i in., słowo/ obraz / terytoria, 2009.

Hames, Peter. "Interwiev with Jan Švankmajer". Dark Alchemy: The Films of Jan Švankmajer, edited by Peter Hames, Flick Books 1995, p. 104.

Jan Paweł II. Dzieła zebrane. Tomy 1-16. Wydawnictwo M, 2007. 
Jan Paweł II. „Rozważanie przed modlitwą «Regina caeli»”, 21 maja 1995, Ołomuniec, Czechy, opoka. org.pl/biblioteka/W/WP/jan_pawel_ii/modlitwy/ap_olomuniec_21051995.html. Dostęp 22.08.2019.

Jonze, Spike, i Kinga Dębska. „Tunel w murze”. Rozmowę przeprowadziła Kinga Dębska. Wprost, nr 17, 2000, s. 108.

Kałużyński, Zygmunt, i Tomasz Raczek. „Podróż do wnętrza Malkovicha”. Rozmawiają Zygmunt Kałużyński i Tomasz Raczek [Być jak John Malkovich - recenzja]. Wprost, nr 19, 2000, ss. 102-103. Kopaliński, Władysław. Słownik symboli. Wiedza Powszechna, 1990.

Kornatowska, Maria. „Orson Welles kontra John Malkovich” [Być jak John Malkovich - recenzja]. Kino, nr 4, 2000, ss. 39-40.

Král, Petr. Private Screening. Translated by P. Hammond, Frisson, 1985.

Pasek, Beata. „Co ty wiesz o Malkovichu?” [Być jak John Malkovich - recenzja, 1999], www.filmweb. $\mathrm{pl} /$ reviews/recenzja-filmu-By\%C4\%87+jak+John+Malkovich-71. Dostęp 15.02.2020.

Pawlukiewicz, Piotr. „Wyruszyć w dal, by wrócić do samego siebie (konferencja)”, 2012, www.youtube. $\mathrm{com} /$ watch?v=_Ej9Znjt-ig. Dostęp 03.04.2020.

Saunders, Nicholas. Dusze zwierzat. Thum. Zbigniew Dalewski, MUZA SA, 1996.

Seul, Anastazja. Literatura polska w wypowiedziach Jana Pawła II. Sacrum. Prawda. Dobro. Piękno. Wydawnictwo Rys, 2014.

Švankmajer, Jan. „Jestem surrealistą”. Rozmowa Bogusław Zmudziński. Przeł. Ján Golian, Kino, nr 4 , 2002, ss. 23, 56.

Szczerba, Jacek. „John Malkovich chce być kimś lepszym” [Być jak Stanley Kubrick - recenzja]. Gazeta Wyborcza, wyd. zasadnicze, nr 94, 2006, s. 17.

Tomaszewska, Ewa. Tam i z powrotem. Rzecz o lalkarskich kontaktach polsko-czechosłowackich i polsko-czesko-słowackich na Śląsku. Wydawnictwo Uniwersytetu Śląskiego, 2019.

Wielebska, Kamila. „Miłość szalona między obsesją a mitem”. Dzieje grzechu. Surrealizm w kinie polskim, red. Kamila Wielebska i Kuba Mikurda, Korporacja Ha!art, 2010.

Wiśniewska, Monika. „Wieczne życie w czyjejś głowie” [Być jak John Malkovich - recenzja]. Przeglad Tygodniowy, nr 15, 2000, s. 20.

Zarębski, Konrad J. „Rozkosze surrealizmu” [Spiskowcy rozkoszy - recenzja]. Kino, nr 12, 2003, s. 35.

\section{FILMOGRAFIA}

Armageddon, reż. Michael Bay. Touchstone Pictures, 1998.

Banal, reż. Cesar Apolinario. APT Entertainment, 2008.

Być jak John Malkovich (ang. Being John Malkovich), reż. Spike Jonze. Gramercy Pictures, Propaganda Films, 1999.

Detektyw w sutannie (ang. Father Dowling). The Fred Silverman Company, Dean Hargrove Productions, Viacom Productions, 1989-1991.

Eureka Street, reż. Adrian Shergold, odc. 1. (13 września 1999). BBC Northern Ireland, 1999.

Kiler-ów 2-óch, reż. Juliusz Machulski. Studio Filmowe ZEBRA, 1999.

Naga broń 33 1/3: Ostateczna zniewaga (The Naked Gun 33 1⁄3: The Final Insult), reż. Peter Segal. Paramount Pictures, 1994.

Opowieść kryminalna (wł. Romanzo criminale, ang. Crime novel), reż. Michele Placido. Cattleya, Babe Film, Warner Bros, Aquarius Films, 2005.

Różowa Pantera (ang. The Pink Panther), reż. Shawn Levy. Metro-Goldwyn-Mayer, Columbia Pictures, Robert Simonds Productions, 2006.

Spiskowcy rozkoszy (czes. Spiklenci slasti), reż. Jan Švankmajer. Athanor, Delfilm, Koninck Studios, 1996.

Zbrodnia ojca Amaro (hiszp. El crimen del padre Amaro), reż. Carlos Carrera. Alameda Films, Artcam International, Blu Films et al, 2002. 


\section{JAN PAWEŁ II W SURREALISTYCZNYCH ODSŁONACH \\ DWA FILMY - O TEATRACH I TEATRZYKACH \\ I NIE TYLKO - „Z UDZIAŁEM” PAPIEŻA}

Streszczenie

Przedmiotem refleksji zawartej w artykule są takie surrealistyczne filmy, jak Spiskowcy rozkoszy (czes. Spiklenci slasti, reż. Jan Švankmajer, 1996) i Być jak John Malkovich (Being John Malkovich, reż. Spike Jonze, 1999), w których zostały użyte w formie montażu materiały archiwalne z udziałem Jana Pawła II, a teatr odgrywa dość znaczącą rolę bądź jako jeden z wiodących tematów, bądź też jako konwencja artystyczna. Autorka zastanawia się, jaki sens mają te przywołania i co ewentualnie komunikują.

W obu analizowanych dziełach wstawki filmowe z Janem Pawłem II wyłamują się z naturalnego porządku rzeczy, są dodatkiem w świecie przedstawionym, elementem innej rzeczywistości i przez to doskonale nadają się jako komponent sztuki surrealistycznej, której jednym z ,zadań” jest wywoływanie konsternacji przez umyślne niedopasowanie prezentowanych elementów. Jan Paweł II w tych montażach staje się ikoną powagi i najdonioślejszych wydarzeń w świecie, ale też sui generis „gwiazdą”, celebrytą, postacią medialną. Zderzenie powagi z groteskowym światem bohaterów wywołuje często efekt dysonansu i konsternację, tym bardziej że oba filmy opowiadają o uleganiu różnym, nieraz całkiem absurdalnym namiętnościom. W Spiskowcach rozkoszy są to przede wszystkim żądze erotyczne i seksualne; w Być jak John Malkovich - żądze powodzenia i sławy (obok różnych konfiguracji żądz zmysłowych). Dochodzi do tego wyraźnie wyeksponowane marzenie, by być kimś innym oraz marzenia o ziemskiej nieśmiertelności. Jan Paweł II nie podzielał takich marzeń, ufając, że najważniejsze jest spełnianie woli Bożej, poczucie własnej wartości w świetle ewangelicznej prawdy o Transcendencji i o ukochaniu każdego człowieka przez Chrystusa oraz „powrót do siebie” - granie swojej, nie cudzej roli. Papież całym swoim życiem pokazywał, jak przekraczać własne przyzwyczajenia, jak ponad wszystko czcić Boga; jak wychodzić naprzeciw drugiemu człowiekowi, pokonując egoizm i rezygnując z wygody. Jak żyć realnie, w rzeczywistej, a nie iluzorycznej - jak bohaterowie omawianych tu filmów - przestrzeni.

Słowa kluczowe: Jan Paweł II; Jan Švankmajer; Spike Jonze; surrealizm; teatr lalkowy; marionetka

\section{SURREALISTIC VERSIONS OF JOHN PAUL II}

TWO FILMS - ABOUT THEATRES, AND NOT ONLY - "FEATURING" THE POPE

\section{Su m mary}

The subject of this paper are such surrealistic films as Conspirators of Pleasure (Czech: Spiklenci slasti, by Jan Švankmajer, 1996) and Being John Malkovich (by Spike Jonze, 1999), in which John Paul II is featured in the form of a montage, and theatre also plays an important role, as either one of the leading topics or else as an artistic convention. The author questions the sense of these references and what can they possibly communicate.

In both of the films analysed, the interpolations of John Paul II usually break out of the normal order of things; they are additions to the represented world, elements of another reality, and thus constitute a perfect component of surrealist art, which aims - among other things - to increase confusion by the intentional incongruity of the elements presented. In these montages, John Paul II becomes an icon of seriousness, gravitas and the most important events in the world, but also a sort of "star," a celebrity, a media person. The clash between this gravitas and the grotesque world of the movie characters often elicits dissonance and confusion, as both movies are concerned with yielding to various, sometimes 
completely absurd, passions. In Conspirators of Pleasure this means - above all - erotic and sexual desires; in Being John Malkovich - a desire for success and fame (apart from various configurations of sensual lust). Additionally, there is the clearly emphasised dream of being somebody else, as well as dreams of earthly immortality. John Paul II did not share such dreams, believing that the most important things are conforming to God's will, one's self-esteem in the light of the evangelical truth about Transcendence and Christ's love towards men, and the "return to oneself" - playing one's own role, not somebody else's. The Pope exemplified with his own life how to go beyond one's own habits, how to worship God above everything else, how to respond to other people, defeat egoism and resign from comfort, and how to live a real life in a real space, not an illusory one, unlike the characters in the above-mentioned movies.

Keywords: John Paul II; Jan Švankmajer; Spike Jonze; surrealism; puppetry; marionette 